\section{Potato Leafhopper Control and Plastic Mulch Culture in Organic Potato Production}

\author{
Martha Maletta ${ }^{1}$, Melvin Henninger ${ }^{2}$, and Kristian Holmstrom ${ }^{3}$
}

AdDitional INDEX WORDs. Solanum tuberosum, Empoasca fabae, pyrethrin, kaolin, silicon dioxide, hopperburn, yield

SUMmary. Control tactics for potato leafhopper (Empoasca fabae) in certified organic potato (Solanum tuberosum) production were evaluated in 2003 and 2004. The 2004 split plot trial also compared silver plastic mulch culture with bare ground culture. The trials were conducted at the Rutgers Snyder Research and Extension Farm's certified organic fields, and production practices conformed to the standards of the National Organic Program (NOP). 'Superior' potato was grown both years. Potato leafhopper (PLH) controls evaluated were: kaolin, pyrethrin, pyrethrin plus kaolin (2003), pyrethrin with silicon dioxide (2004), and silver plastic mulch (2003). Pyrethrin, pyrethrin plus kaolin, and pyrethrin with silicon dioxide reduced PLH nymph counts and PLH damage (hopperburn) ratings compared with the untreated check (UTC). Kaolin did not reduce nymph counts or hopperburn ratings. In 2003, nymph counts and hopperburn ratings were higher in the mulch treatment than in the UTC, yet the mulch treatment produced higher yield than the UTC. In 2004, mulch culture increased total and marketable yield compared with bare ground culture when PLH was controlled. Nymph counts and hopperburn ratings were higher until mid-July in the mulch plots than bare ground plots with the UTC and kaolin treatments. Controlling PLH and using plastic mulch culture significantly increased organic potato yields and tuber size. Marketable yields from the UTC were less than the New Jersey average of $275 \mathrm{cwt} /$ acre for conventionally grown potato: yield was $38 \%$ of average on bare ground and $68 \%$ of average on mulch in $2003 ; 33 \%$ of average on bare ground and $38 \%$ of average on mulch in 2004 . Reducing hopperburn with pyrethrin on plants grown on mulch (2004) resulted in marketable yield that was $75 \%$ of the New Jersey average.

$\mathrm{P}$ otato leafhopper (Family: Cicadellidae, Order: Homoptera) feeds on foliage of potatoes and more than 200 other plant species. In the United States it overwinters in locations along the Gulf of Mexico. Mated females constitute the majority of insects that migrate north during spring, spreading to most states east of the Rocky Mountains and arriving in New Jersey in late May to early June. Feeding and egg laying begin immediately. Nymphs pass through five instars, all capable of foliar feeding, and there are several generations per season. Foliar feeding results in the

\footnotetext{
The authors thank the Rutgers Snyder Research and Extension Farm for granted financial support and the staff for practical support. We thank Dr. Richard Trout for statistical advice. The trade or brand names given herein are supplied with the understanding that no discrimination is intended and no endorsement by Rutgers Cooperative Research and Extension is implied.

${ }^{1}$ Rutgers Cooperative Research and Extension of Hunterdon County, P.O. Box 2900, Flemington, NJ 08822

${ }^{2}$ Department of Plant Biology and Pathology, Cook College, New Brunswick, N.J.

${ }^{3}$ Pest Management Office, Cook College, New Brunswick, N.J.
}

symptom called hopperburn that, in potatoes, appears first as upward curling of leaflet margins. Necrosis due to phloem blockage caused by mechanical feeding injury and the plant's response to PLH-injected saliva progresses from leaflet margin to mid-vein, blighting and killing foliage. Hopperburn can significantly reduce tuber yields ( $\mathrm{Pe}$ terson and Granovsky, 1950).

Rutgers Cooperative Research and Extension recommends that commercial potato growers monitor their fields and apply insecticides to control PLH (Garrison, 2005). These insecticides are not allowed in certified organic production, and PLH can cause devastating yield losses for or- ganic potato growers who have limited control options. Maine's 2001 organic potato crop was reported to have been devastated because of a severe PLH infestation (E. Sideman, personal communication). In Massachusetts, organic potato production has been limited by PLH (R. Hazzard, personal communication). A long-time New Jersey organic grower stopped growing potatoes after many years, in part because of PLH damage (E. Lidzbarski, personal communication).

Published research on PLH control for certified organic production is limited. Kaolin reduced PLH numbers and damage but did not improve yields compared with an untreated control in a non-organic efficacy trial (Seaman, 2002). Kaolin reduced PLH damage on eggplant (Solanum melogena) (Maletta et al., 2004). Pyrethrin reduced PLH in alfalfa (Medicago sativa) $2 \mathrm{~d}$ but not $7 \mathrm{~d}$ and $13 \mathrm{~d}$ after treatment, but pyrethrin with silicon dioxide was not effective (Dively et al., 2003 ) although pyrethrin with silicon dioxide provided up to $75 \%$ control of PLH on snap bean (Phaseolusvulgaris) (Dively, 2003). Repeated applications of pyrethrin reduced PLH populations in alfalfa and eggplant (Dively et al., 2004).

The number of certified organic farms has increased in New Jersey (E. Bremmer, personal communication) and nationwide in recent years (Dimitri and Greene, 2002; Willer and Yussefi, 2004). With increases in organic production and final passage of the National Organic Program (NOP) in 2002, the Organic Materials Review Institute (OMRI, Eugene, Ore.) reported an increase in new pest control products being submitted for review and approval for use in certified organic crop production (E. Brown-Rosen, personal communication). Research-based efficacy data on these materials would be valuable to organic vegetable growers, including those transitioning to organic produc-

\begin{tabular}{lllc}
\hline $\begin{array}{l}\text { Units } \\
\text { To convert U.S. to SI, } \\
\text { multiply by }\end{array}$ & U.S. unit & SI unit & $\begin{array}{l}\text { To convert SI to U.S., } \\
\text { multiply by }\end{array}$ \\
\hline 112.0851 & $\mathrm{cwt} / \mathrm{acre}$ & $\mathrm{kg} \cdot \mathrm{ha}^{-1}$ & 0.0089 \\
0.3048 & $\mathrm{ft}$ & $\mathrm{m}$ & 3.2808 \\
9.3540 & gal/acre & $\mathrm{L} \cdot \mathrm{ha}^{-1}$ & 0.1069 \\
2.5400 & inch $(\mathrm{es})$ & $\mathrm{cm}$ & 0.3937 \\
1.1983 & $\mathrm{lb} / \mathrm{l00} \mathrm{gal}$ & $\mathrm{g} \cdot \mathrm{L}^{-1}$ & 0.8345 \\
1.1209 & $\mathrm{lb} / \mathrm{acre}$ & $\mathrm{kg} \cdot \mathrm{ha}^{-1}$ & 0.8922 \\
0.0254 & mil & $\mathrm{mm}$ & 39.3701 \\
6.8948 & $\mathrm{psi}$ & $\mathrm{kPa}$ & 0.1450
\end{tabular}


tion, and to university personnel and others who provide technical support for these growers.

\section{Materials and methods}

The efficacy of four insect control products or combinations of products, approved for certified organic production and labeled for controlling PLH on potato, was evaluated in 2003 and 2004 at the Rutgers Snyder Research and Extension Farm in Pittstown, N.J. The materials had become available for grower use since 2000. The 2003 trial also included silver plastic mulch as a PLH control treatment. A New Jersey certified organic grower reported his experience that “... (potato) plants did appear to have less of a problem with leafhoppers on the metallized (silver) mulch..." (J. Kinsel, personal communication), and reflective mulch was reported to reduce corn leafhopper (Dalbulusmaidis) numbers (Summers and Stapleton, 2002). In 2004 silver plastic mulch culture was compared with bare ground culture to investigate yield effects seen in the 2003 trial. The experimental design with six replications was a randomized complete block in 2003 and a split plot in 2004 with culture (plastic mulch or bare ground) as the main plot and PLH control treatment as the subplot.

Research plots of 'Superior' potato were established on the Rutgers Snyder Research and Extension Farm's certified organic fields, and all production practices conformed to the NOP standards. The soil was a Quakertown silt loam (fine-loamy, mixed, mesic, Typic Hapludult). In 2003 and 2004, a $3 \mathrm{~N}-0.9 \mathrm{P}-2.5 \mathrm{~K}$ fertilizer(Feed-N-Gro; Fertrell, Bainbridge, Pa.) was broadcast at $1000 \mathrm{lb} /$ acre and disked in before planting. In 2003, a $12 \mathrm{~N}-0 \mathrm{P}-0 \mathrm{~K}$ fertilizer (Bloodmeal; Fertrell) was sidedressed at $542 \mathrm{lb} /$ acre when plants were 2 to 4 inches tall. In 2004, the $12 \mathrm{~N}-0 \mathrm{P}-0 \mathrm{~K}$ fertilizer was broadcast in the raised bed area at $583 \mathrm{lb} /$ acre just before bed making. An estimated additional $25 \mathrm{lb} /$ acre of nitrogen was credited from the winter rye (Secale cereale) and hairy vetch (Vicia villosa) cover crop. Weeds were controlled with tractor and hand cultivation in bare ground rows and middles. Weeds in plastic row middles were controlled with hand cultivation and, in 2004, with clove oil (Matran 2; EcoSMART Technologies, Franklin, Tenn.) and a 4- to 6-inch layer of straw.
Seed pieces were planted 9 inches apart in rows spaced at $3.0 \mathrm{ft}(2003)$ or $3.75 \mathrm{ft}$ (2004). A treatment plot consisted of three single rows, $21 \mathrm{ft}$ long, with 28 plants each. Data were taken from the middle row. There were 12 - to 15 - $\mathrm{ft}$ breaks between plots in the rows and 6- to 8 - $\mathrm{ft}$ driveways separating every three rows. In 2003 , the rows were tractor-furrowed, and the seed pieces were hand-placed in all but the mulch treatment plots and covered. Silver plastic mulch [1.0 mil thick, $4 \mathrm{ft}$ wide (Pliant; Rain Flo Irrigation, East Earl, Pa.)] was installed manually in the plots designated for that treatment. Planting holes were cut through the mulch and into the soil with a manual bulb planter, the seed pieces inserted, and holes filled by hand. Trickle irrigation was installed in all plots, lying under the mulch and on the surface in the bare ground plots. In 2004 , the silver plastic mulch (1.0 mil thick, $3 \mathrm{ft}$ wide (Robert Marvel Plastic Mulch and Irrigation, Annville, Pa.)] and trickle irrigation tape were installed on raised beds with a bed maker (model RBA36; Nolt's Produce Supplies, Leola, Pa.). Bare ground treatment rows were also prepared as raised beds. Planting holes were opened in the mulch with a water wheel transplanter (model 1406; Kennco Mfg., Ruskin, Fla.). Holes were manually enlarged, as needed, the seed pieces inserted, and holes filled. For bare ground rows, seed piece placement was marked with the transplanter, seed pieces placed by hand and covered using the bed maker. Trickle irrigation was installed on the bare ground rows. The crop was planted 29 Apr. 2003 and 11 May 2004 and harvested on 18 Aug. 2003 and 10 Aug. 2004.

Colorado potato beetles (Leptinotarsa decemlineata), the only nontarget pest present in the plots and in very low numbers, were controlled by hand-picking in 2003 and by hand-picking and one application of spinosad at $0.10 \mathrm{lb} /$ acre a.i (Entrust; Dow AgroSciences, Indianapolis) in 2004. Foliar disease was not a factor in either year.

PLH control materials evaluated in 2003 and 2004 were: kaolin at 23.75 lb/l00 gal a.i. (Surround WP; Engelhard Corp., Iselin, N.J.); pyrethrin at $0.015-0.03 \mathrm{lb} /$ acre a.i. (Pyganic EC 1.4; McLaughlin Gormlely King Co., Minneapolis). Also evaluated were: kaolin plus pyrethrin (2003), silver plastic mulch (2003), pyrethrin at $0.01-0.02 \mathrm{lb} /$ acre a.i. with silicon dioxide at $1.65-3.30 \mathrm{lb} /$ acre a.i. (Diatect V; Diatect International, Heber, Utah) (2004).

In 2003, PLH controls were applied with a backpack sprayer (model 475; Solo Inc., Newport News, Va.) delivering $69 \mathrm{gal} /$ acre or a tractor mounted carbon dioxide $\left(\mathrm{CO}_{2}\right)$ sprayer (custom-made) delivering $65 \mathrm{gal} / \mathrm{acre}$ at 30 psi using Conejet 8003 nozzles (Spraying Systems Co., Wheaton, Ill.). Applications were begun when 10 PLH adults were netted in 50 sweeps in the field and repeated as close to weekly as soil and weather conditions permitted. Six applications were made: 11 and 23 June; 1, 9, 17, and 28 July. In 2004, PLH controls were applied with a tractor-mounted diaphragm pump sprayer (model Super A; Case Corp., Racine, Wis.) with offset boom. Materials were applied at 60 psi using XR Teejet 8004 nozzles (Spraying Systems Co.) that delivered $67 \mathrm{gal} / \mathrm{acre}$. Kaolin was first applied as soon as plants emerged. Pyrethrin and pyrethrin with silicon dioxide treatments began when PLH adults were first collected with a sweep net (two per 50 sweeps) and repeated as close to weekly as soil and weather conditions allowed. Nine applications were made: 26 May (kaolin only); 3, 9, 16, 24, 30 June; 7, 20, 27 July.

Data collected were number of PLH adults per 10 sweeps of a 15inch-diameter net; number of PLH nymphs per 10 leaves; hopperburn rating. Nymphs were collected by manually agitating 10 randomly selected mature, mid-canopy leaves, which remained attached to the plant, in a water-household detergent solution in a plastic bag. The nymphs were filtered out with a basket-type coffeemaker paper filter, which was then spread over a grid, and counted. Hopperburn rating was a visual estimate of the percent foliar necrosis most prevalent in the data row, based on the 1 to 8 scale of Granovsky and Peterson (Granovsky and Peterson, 1954). Potato tubers were machine-dug, hand-collected, graded, sized, and weighed. (Yields for both years are reported as hundredweight per acre.)

All data were subjected to appropriate analysis of variance using SuperAnova (Abacus Concepts, Berkeley, Calif.). Means separation was by Fisher's protected least significant difference (LSD) at $P=0.05$. When 
significant interactions were found, the means associated with the interaction were compared using the least significant difference (LSD), appropriate standard errors being determined using the methods shown in Steel and Torrie (1980).

\section{Results, 2003}

Adult counts done a few hours after treatment applications were lower in pyrethrin and kaolin plus pyrethrin-treated plots and higher in the mulch plots than in the UTC and kaolin-treated plots $(\mathrm{df}=4,17 ; \mathrm{F}=$ 39.6; $P \leq 0.0001$ ) (Table 1). Counts were lower in the pyrethrin-treated plots than in the kaolin plus pyrethrintreated plots.

Pyrethrin and kaolin plus pyrethrin treatments significantly reduced the number of PLH nymphs on 7 and 15 July $(\mathrm{df}=4,17 ; \mathrm{F}=39.62 ; P \leq 0001$ and $\mathrm{df}=4,20 ; \mathrm{F}=37.01 ; P \leq 0.0001)$ and hopperburn rating on 14 and 28 July $(\mathrm{df}=4,20 ; \mathrm{F}=20.64 ; P \leq 0.0001$ and $\mathrm{df}=4,20 ; \mathrm{F}=65.59 ; P \leq 0.0001)$ compared to the UTC and kaolin treatments, which were not different (Table 1). PLH adult count, nymph counts, and hopperburn ratings were higher in the mulch plots than in the UTC (Table 1). However, total yield $(\mathrm{df}=4,20 ; \mathrm{F}=29.25 ; P \leq 0.0001)$ and marketable yield (tubers $1-7 / 8$ to 4 inches in diameter and reasonably free of defects $)(\mathrm{df}=4,20 ; \mathrm{F}=41.90 ; P$ $\leq 0.0001$ ) from the mulch plots were significantly higher than from the other treatments (Table 1). Total yields from pyrethrin, kaolin plus pyrethrin, and kaolin-treated plots, which were not different, were about $50 \%$ higher than yields from the UTC. Marketable yield was higher from the pyrethrin and kaolin plus pyrethrin-treated plots than from the kaolin-treated plots and UTC (Table 1). Pyrethrin, kaolin plus pyrethrin, and silver mulch treatments increased tuber size $(\mathrm{df}=4,20 ; \mathrm{F}=$ $6.49 ; P \leq 0.0016$ ), as indicated by the higher percent yield of tubers larger than 1-7/8-inch diameter, compared with the UTC. The percentage of tubers $>2-1 / 2$ inches in diameter was not affected by treatment.

\section{Results, 2004}

Analysis of variance indicated there was no significant interaction of treatment and culture for PLH adult counts, nymph counts on 14 July, hopperburn ratings on 28 July, total and marketable yield, or percentage of tubers with $>1-7 / 8$-inch diameter (Table 2). Means were averaged across treatment or across culture. There was significant treatment $\times$ culture interaction for nymph counts on 28 June, hopperburn ratings on 14 July, and percentage of tubers $>2-1 / 2$ inches in diameter (Table 2).

Adult PLH counts done $1 \mathrm{~d}$ after treatment on 17 June were higher ( $\mathrm{df}$ $=1,4 ; \mathrm{F}=21.77 ; P \leq 0.0095)$ in the mulch plots than in the bare ground plots (Table 3). Pyrethrin and pyrethrin with silicon dioxide treatments

Table 1. Effect of pest control treatment on potato leafhopper (PLH) numbers, foliar damage (hopperburn), yield, and tuber size of 'Superior' potato in a 2003 trial at Rutgers Snyder Research and Extension Farm in Pittstown, N.J.

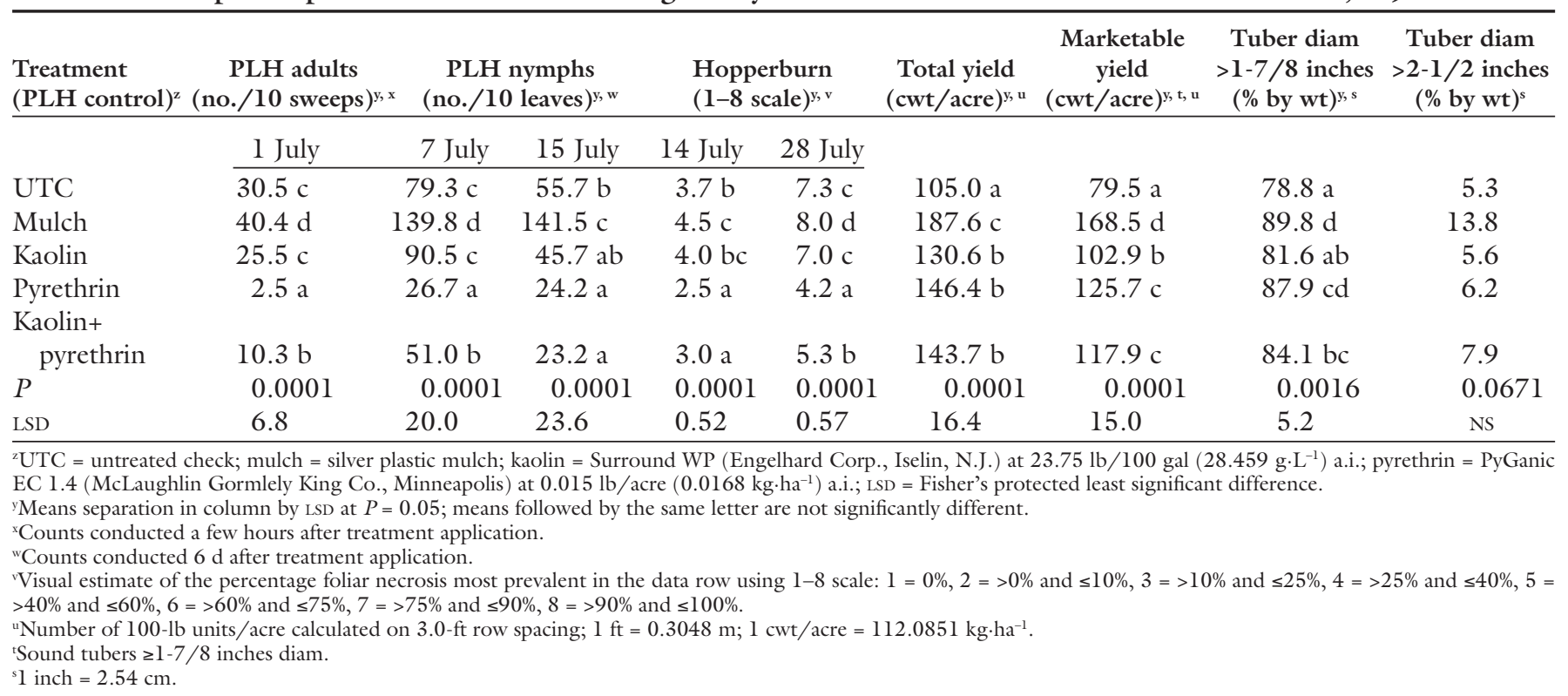

Table 2. Split plot analysis of variance probability values for main effects and interaction of pest control treatment and culture for potato leafhopper (PLH) numbers, foliar damage (hopperburn), yield and tuber size of 'Superior' potato in a 2004 trial at Rutgers Snyder Research and Extension Farm in Pittstown, N.J.

\begin{tabular}{|c|c|c|c|c|c|c|c|c|c|c|}
\hline & \multirow[t]{2}{*}{ df } & $\begin{array}{l}\text { PLH } \\
\text { adults }\end{array}$ & \multicolumn{2}{|c|}{$\begin{array}{c}\text { PLH } \\
\text { nymphs }\end{array}$} & \multicolumn{2}{|c|}{ Hopperburn } & \multirow[t]{2}{*}{$\begin{array}{l}\text { Total } \\
\text { yield }\end{array}$} & \multirow[t]{2}{*}{$\begin{array}{c}\text { Marketable } \\
\text { yield }\end{array}$} & \multirow[t]{2}{*}{$\begin{array}{c}\text { Tuber diam } \\
>1-7 / 8 \\
\text { inches }^{\mathrm{z}}\end{array}$} & \multirow[t]{2}{*}{$\begin{array}{c}\text { Tuber diam } \\
2-1 / 2 \\
>\text { inches } \\
\end{array}$} \\
\hline & & 17 June & 28 June & 14 July & 14 July & 28 July & & & & \\
\hline Pest control treatment & 3 & 0.0110 & 0.0001 & 0.0001 & 0.0001 & 0.0001 & 0.0001 & 0.0001 & 0.0120 & 0.0001 \\
\hline Culture & 1 & 0.0095 & 0.0105 & 0.9434 & 0.0003 & 0.0519 & 0.0167 & 0.0692 & 0.6366 & 0.7474 \\
\hline Treatment $\times$ culture & 3 & 0.2254 & 0.0473 & 0.9862 & 0.0001 & 0.0663 & 0.1249 & 0.2231 & 0.4095 & 0.0011 \\
\hline
\end{tabular}

${ }^{2} 1$ inch $=2.54 \mathrm{~cm}$ 
reduced counts $(\mathrm{df}=3,24 ; \mathrm{F}=4.61$; $P \leq 0.0110)$ compared to the UTC. Six days after application, there were no differences in adult counts among all treatments (data not shown).

Pyrethrin and pyrethrin with silicon dioxide treatments reduced the number of PLH nymphs on 14 July $(\mathrm{df}=3,30 ; \mathrm{F}=54.55 ; P \leq 0.0001)$ and hopperburn rating on 28 July $(\mathrm{df}=3,30 ; \mathrm{F}=320.38 ; P \leq 0.0001)$ compared with the UTC and kaolin treatments (Table 3). Pyrethrin-treated plots had lower nymph counts and less hopperburn than pyrethrin with silicon dioxide-treated plots (Table 3 ). Nymph count and hopperburn did not differ with culture (Table 3 ).

Total yield $(\mathrm{df}=3,28 ; \mathrm{F}=23.27$; $P \leq 0.0001)$ and marketable yield $(\mathrm{df}$ $=3,28 ; \mathrm{F}=21.09 ; P \leq 0.0001$ ) was highest from pyrethrin-treated plots (Table 3). Pyrethrin with silicon dioxide treatment also increased total and marketable yields compared with the kaolin treatment and the UTC, which did not differ. Total yield was higher $(\mathrm{df}=1,5 ; \mathrm{F}=12.47 ; P \leq 0.0167)$ from the mulch plots than from the bare ground plots (Table 3). Mulch increased marketable yield, but the increase was nonsignificant $(\mathrm{df}=1,5$; $\mathrm{F}=5.32 ; P \leq 0.0692)$. Pyrethrin and pyrethrin with silicon dioxide treat- ments increased tuber size $(\mathrm{df}=3,28$; $\mathrm{F}=4.38 ; P \leq 0.0120)$ as indicated by the higher percentage of tubers $>1-7 / 8$ inch in diameter compared to the UTC (Table 3); there was no effect of culture $(\mathrm{df}=1,5 ; \mathrm{F}=0.25 ; P \leq 0.6366)$.

There was a significant interaction effect of treatment $\times$ culture on PLH nymph count on 28 June $(\mathrm{df}=3,30$; $\mathrm{F}=2.97 ; P \leq 0.0473)$ and hopperburn on 14 July $(\mathrm{df}=3,30 ; \mathrm{F}=12.05 ; P$ $\leq 0.0001)$. Considering treatment differences within culture, pyrethrin treatment reduced nymph count $(\mathrm{LSD}=$ 12.3) compared to all other treatments in both mulch and bare ground culture (Table 4). Pyrethrin with silicon dioxide reduced nymph count compared to UTC only in mulch culture, but reduced hopperburn compared to the UTC in both cultures. Kaolin treatment actually increased hopperburn rating with mulch culture compared to the UTC. Considering differences between cultures within each treatment ( $\mathrm{LSD}=16.7$ ), the UTC and kaolin-treated mulch plots had significantly higher nymph counts than the bare ground plots; there was no difference between cultures for the pyrethrin and pyrethrin with silicon dioxide treatments (Table 4). Hopperburn rating shows a similar interaction, being higher with mulch than bare ground culture $(\mathrm{LSD}=0.45)$ for the treatments that did not control PLH nymphs (Table 4). Tuber size, as indicated by percentage of tubers larger than $2-1 / 2$ inches in diameter, was increased by the pyrethrin treatment in both cultures, but by silicon dioxide with pyrethrin only in plastic culture $($ LSD $=12.12)($ Table 4$)$. Culture did not affect tuber size for any treatment $($ LSD $=19.41)$.

\section{Discussion}

In these trials, controlling PLH and reducing hopperburn significantly increased total and marketable potato yields. Pyrethrin was the most effective control in both years. Kaolin plus pyrethrin (2003) and pyrethrin with silicon dioxide (2004) were generally not as effective as pyrethrin alone. The pyrethrin rate was the same for both 2003 treatments, so the result suggests that kaolin interfered with pyrethrin effectiveness. In 2004, the rate of pyrethrin applied as Diatect was less then the rate of the pyrethrin-only treatment, which could account for it being less effective. Kaolin did not control PLH or reduce hopperburn compared to the untreated control in either year. Although plastic mulch culture increased PLH population and hopperburn in the plots where PLH was not controlled, it also significantly

Table 3. Effect of pest control treatment and culture on potato leafhopper (PLH) numbers, foliar damage (hopperburn), yield and tuber size of 'Superior' potato in a 2004 trial at Rutgers Snyder Research and Extension Farm in Pittstown, N.J. Means comparisons are for variables with no significant culture $\times$ treatment interaction. Treatment means were averaged across culture; culture means were averaged across treatment.

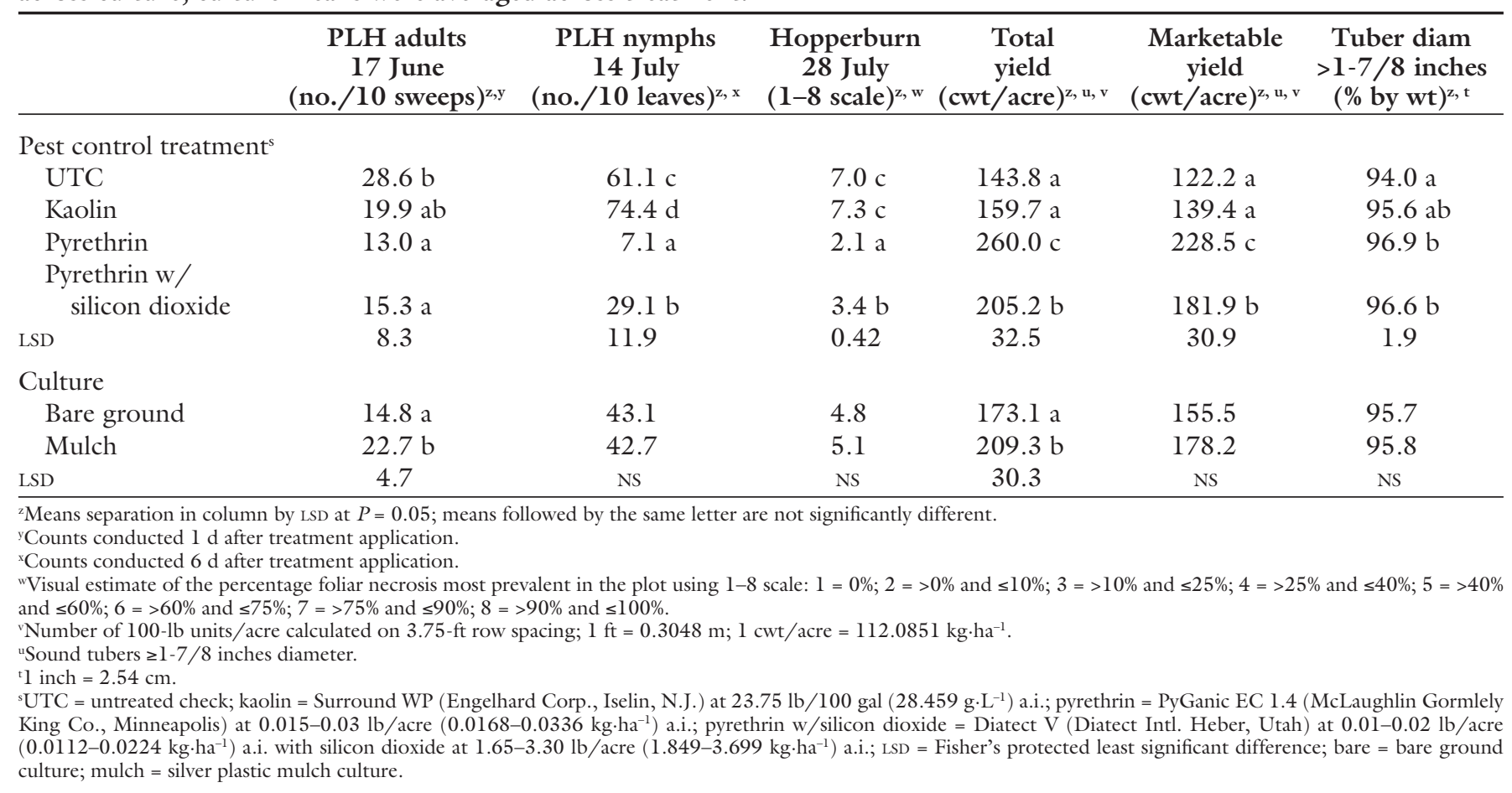


Table 4. Effect of pest control treatment and culture on potato leafhopper (PLH) numbers, foliar damage (hopperburn) and tuber size of 'Superior' potato in a 2004 trial at Snyder Research and Extension Farm in Pittstown, N.J. Means for variables with significant culture $\times$ pest control interaction are compared among pest control treatments for each culture and between cultures for each pest control treatment.

\begin{tabular}{|c|c|c|c|}
\hline & $\begin{array}{c}\text { PLH nymphs } \\
\text { 28 June } \\
{\text { (no./10 leaves) })^{z, y}}\end{array}$ & $\begin{array}{c}\text { Hopperburn } \\
\text { 14 July } \\
(1-8 \text { scale })^{z, x} \\
\end{array}$ & $\begin{array}{l}\text { Tuber diam } \\
>2-1 / 2 \text { inches } \\
(\% \text { by wt })^{z, w}\end{array}$ \\
\hline \multicolumn{4}{|l|}{$\operatorname{Bare}^{v}$} \\
\hline UTC & $22.8 \mathrm{bc}$ & $2.7 \mathrm{c}$ & $42.5 \mathrm{a}$ \\
\hline Kaolin & $30.3 \mathrm{c}$ & $2.9 \mathrm{c}$ & $49.8 \mathrm{a}$ \\
\hline Pyrethrin & $4.7 \mathrm{a}$ & $1.5 \mathrm{a}$ & $65.2 \mathrm{~b}$ \\
\hline \multicolumn{4}{|l|}{ Pyrethrin w/ } \\
\hline \multicolumn{4}{|l|}{ Mulch } \\
\hline UTC & $46.3 \mathrm{c}$ & $3.8 \mathrm{~b}$ & $36.0 \mathrm{a}$ \\
\hline Kaolin & $48.2 \mathrm{c}$ & $4.6 \mathrm{c}$ & $39.3 \mathrm{a}$ \\
\hline Pyrethrin & $7.2 \mathrm{a}$ & $1.8 \mathrm{a}$ & $70.0 \mathrm{~b}$ \\
\hline $\begin{array}{l}\text { Pyrethrin w/ } \\
\text { silicon dioxide }\end{array}$ & \multicolumn{2}{|c|}{ Pyrethrin w/ } & $65.7 \mathrm{~b}$ \\
\hline LSD & 12.3 & 0.44 & 12.12 \\
\hline \multicolumn{4}{|l|}{ UTC } \\
\hline Bare & $22.8 \mathrm{a}$ & $2.7 \mathrm{a}$ & $42.5 \mathrm{a}$ \\
\hline Mulch & $46.3 \mathrm{~b}$ & $3.8 \mathrm{~b}$ & $36.0 \mathrm{a}$ \\
\hline \multicolumn{4}{|l|}{ Kaolin } \\
\hline Bare & $30.3 \mathrm{a}$ & $2.9 \mathrm{a}$ & $49.8 \mathrm{a}$ \\
\hline Mulch & $48.2 \mathrm{~b}$ & $4.6 \mathrm{~b}$ & $39.3 \mathrm{a}$ \\
\hline \multicolumn{4}{|l|}{ Pyrethrin } \\
\hline Bare & $4.7 \mathrm{a}$ & $1.5 \mathrm{a}$ & $65.2 \mathrm{a}$ \\
\hline Mulch & $7.2 \mathrm{a}$ & $1.8 \mathrm{a}$ & $70.0 \mathrm{a}$ \\
\hline \multicolumn{4}{|l|}{$\begin{array}{l}\text { Pyrethrin w/ } \\
\text { silicon dioxide }\end{array}$} \\
\hline Bare & $14.0 \mathrm{a}$ & $2.1 \mathrm{a}$ & $49.3 \mathrm{a}$ \\
\hline Mulch & $22.8 \mathrm{a}$ & $2.1 \mathrm{a}$ & $65.7 \mathrm{a}$ \\
\hline LSD & 16.7 & 0.45 & 19.41 \\
\hline \multicolumn{4}{|c|}{ 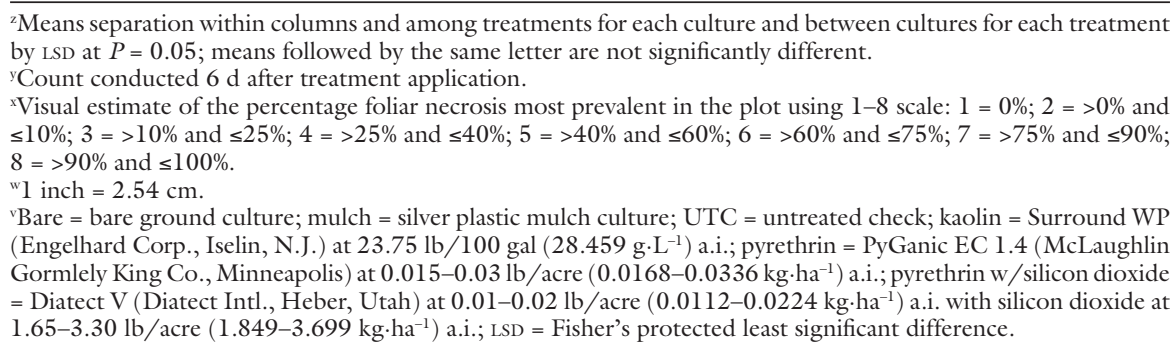 } \\
\hline
\end{tabular}

Table 5. Means of total and marketable yields of 'Superior' potato for selected potato leafhopper control treatment and culture combinations in 2003 and 2004 trials at Snyder Research and Extension Farm in Pittstown, N.J.

\begin{tabular}{|c|c|c|c|c|}
\hline \multirow[b]{2}{*}{ Treatment/culture $^{\mathrm{x}}$} & \multicolumn{2}{|c|}{$\begin{array}{l}\text { Total yield } \\
(\text { cwt/acre })^{z}\end{array}$} & \multicolumn{2}{|c|}{$\begin{array}{c}\text { Marketable yield } \\
(\mathrm{cwt} / \text { acre })^{\mathrm{z}, \mathrm{y}}\end{array}$} \\
\hline & 2003 & 2004 & 2003 & 2004 \\
\hline UTC/bare & 105.0 & 102.0 & 79.5 & 90.0 \\
\hline UTC/mulch & 187.6 & 128.0 & 168.5 & 105.0 \\
\hline Pyrethrin/bare & 146.4 & 182.0 & 125.7 & 164.0 \\
\hline Pyrethrin/mulch & --- & 240.0 & --- & 206.0 \\
\hline
\end{tabular}

${ }^{2}$ Number of $100-\mathrm{lb}$ units/acre calculated on 3.0-ft row spacing (2003) or 3.75-ft row spacing (2004); $1 \mathrm{ft}=$ $0.3048 \mathrm{~m} ; 1 \mathrm{cwt} /$ acre $=112.0851 \mathrm{~kg} \cdot \mathrm{ha}-1$.

y Sound tubers $\geq 1-7 / 8$ inches diameter; $l$ inch $=2.54 \mathrm{~cm}$

${ }^{\mathrm{x}} \mathrm{UTC}=$ untreated check; pyrethrin = PyGanic EC 1.4 (McLaughlin Gormlely King Co., Minneapolis) at 0.015-0.03

$\mathrm{lb} /$ acre $(0.0168-0.0336 \mathrm{~kg} \cdot \mathrm{ha}-1)$ a.i.; bare = bare ground culture; mulch = silver plastic mulch culture increased those total yields in both years. In both years, plants grown on mulch were visibly larger that those grown on bare ground, and this difference might help account for yield increases. The cause of the apparent growth difference was not investigated but might have been related to any of several possible differences between mulch and bare ground culture in soil moisture and/or temperature, weed pressure, nutrient leaching, or reflected light and/or heat.

In 2003, total and marketable yield was highest from the mulchgrown but untreated plants (Table 5 ) that exhibited the most severe hopperburn, so it appeared that mulch culture might compensate for yield reduction due to PLH damage. But, in 2004, mean yields for the UTC in each culture indicated that mulch culture did not compensate similarly for yield reductions due to PLH damage (Table 5). We speculated that cultivation of wet soil in the bare ground plots that occurred in 2003 might have resulted in compaction that caused an exceptional reduction in tuber development, even for plots where treatment reduced hopperburn. The adverse effect of potato bed soil compaction on yield has been demonstrated (Grimes and Bishop, 1971). If this was the case, the apparent beneficial effect of mulch on yield would have been inflated in 2003 .

Pyrethrin treatment increased mean marketable yield in bare ground culture by $58 \%(2003)$ and $82 \%(2004)$ compared to the UTC (Table 5). Under mulch culture, pyrethrin treatment increased mean marketable yield by 96\% (2004). Mean marketable yield for the combination of mulch culture and effective PLH control was 130\% higher than for bare ground culture and no PLH control (Table 5).

Mean marketable yield from the UTC was much lower in both years than the New Jersey average of 275 cwt/acre (based on $3-\mathrm{ft}$ row spacing) for conventionally raised potato: $38 \%$ of average on bare ground and 68\% of average on mulch in $2003 ; 33 \%$ of average on bare ground and $38 \%$ of average on mulch in 2004. In 2003, marketable yield with the most effective PLH control (and bare ground culture) was $46 \%$ of the New Jersey average. In 2004, effective PLH control combined with mulch culture resulted in marketable yield (at 3.75 -ft row spac- 
ing) that was $75 \%$ of the New Jersey average; yield on bare ground was $60 \%$ of the New Jersey average. Combining effective PLH control with silver mulch culture can increase and improve organic potato yields. However, using silver plastic mulch without controlling PLH might not benefit yield and might increase PLH damage.

\section{Literature cited}

Dimitri, C. and C. Greene. 2002. Recent growth patterns in the U.S. organic foods market. 28 Mar. 2005. <www.ers.usda. gov/publications/aib777/>.

Dively, G. 2003. Pest Net 20.28 Mar. 2005. <www.agnr.umd.edu/users/nrsl/entm/ PestNet/PestNetReports\%202003/ PN20.htm>.

Dively, G.P., T. Patton, and A. Miller. 2003. Field efficacy evaluation of selected conventional and organic insecticides for control of insect pests in Maryland. 28 Mar. 2005. <www.mdipm.umd.edu/OrganicFinalReport2003.pdf>.

Dively, G.P., T. Patton, and A. Miller. 2004. Field efficacy evaluation of selected conventional and organic insecticides for control of insect pests in Maryland. 28 Mar. 2005. <www.mdipm.umd.edu/ Galen's\%20articles/OrganicFinalReport2004.pdf>.

Garrison, S.A (ed.). 2005. Commercial vegetable production recommendations. N.J. Agr. Expt. Sta. Publ. E001S.
Granovsky, A.A. and A.G. Peterson. 1954. Evaluaton of potato leaf injury caused by leafhoppers, flea beetles, and early blight. J. Econ. Entomol. 47:894-902.

Grimes, D.W. and J.C. Bishop. 1971. The influence of some soil physical properties on potato yields and grade distribution. Amer. Potato J. 48:414-422.

Maletta, M., W. Tietjen, G. Ghidiu, K. Holmstrom, and W. Cowgill. 2004. Evaluation of controls for flea beetle on eggplant in an organic production system. Acta Hort. 638:341-346.

Peterson, A.G. and A.A. Granovsky. 1950. Relation of Empoasca fabae to hopperburn and yields of potatoes. J. Econ. Entomol. 43:484-487.

Seaman, A. 2002. Efficacy trials of OMRI approved materials on vegetable crops. 28 Mar. 2005. <www.nysipm.cornell. edu/publications/omri.html>.

Steel, R.B. and J.H. Torrie. 1980. Statistics, a biometrical approach, 2nd ed. McGraw Hill, New York.

Summers, C.G. and J.J. Stapleton. 2002. Management of corn leafhopper (Homoptera: Cicadellidae) and corn stunt disease in sweet corn using reflective mulch. J. Econ. Entomol. 95:325-330.

Willer, H. and M. Yussefi (eds.). 2004. The world of organic agriculture: statistics and emerging trends. 28 Mar. 2005. <orgprints. org /2555/01/willer-yussefi-2004-worldof-organic.pdf>. 